\title{
Analisis pengaruh online review pada booking.com terhadap keputusan wisatawan menginap di de vins sky hotel seminyak, bali
}

\author{
Silvia Sevtiani ${ }^{1)}$, Anak Agung Putri Sri ${ }^{2}$, Ni Putu Ratna Sari ${ }^{3)}$ \\ Program Studi Diploma IV Pariwisata, Fakultas Pariwisata, Universitas Udayana ${ }^{123)}$ \\ Jl. Dr. R. Goris No. 7 Denpasar Timur \\ E-mail : sevtianisilvia031@yahoo.co.id
}

\begin{abstract}
Abstrak
Pa da situs untuk online review terdapat beberapa unsur yang sering diba ca yaitu informasi mengenai objek yang dicari, produk yang disajikan baik berupa ulasan, foto, tempat mau pun fasilitas yang diunduh dalam halaman tersebut yang nantinya akan mempengaruhi keputusan untuk menginap pada suatu hotel. Tujuan dari penelitian ini untuk mengetahui pengaruh pasar online review (informasi u mum, ula san, foto, lokasi, dan fasilitas) pada situs booking.com terhadap keputusan wisatawan menginap di De Vins Sky Hotel, Seminyak dan untuk mengetahui variabel yang paling signifikan berpengaruh terhadap keputusan wisatawan menginap di De Vins Sky Hotel, Seminyak. Cara pengumpulan data dila kukan melalui observasi, kuesioner dan studi kepustakaan. Adapun metode penelitian yang digunakan dalam penelitian ini ya itu Analisis Statistik Deskriptif dengan perhitungan skala likert, serta Ana lisis Statistik Inferensial y ang terdiridari a nalisis korelasi, Ana lisis Linear Berganda, Analisis Simultan (Uji F), Ana lisis Parsial(Uji t test), Analisis Determinasi. Hasil penelitian menunjukan bahwa terdapat penganh postif da nsignifik an dari Online Review pa da Booking.com terhadap keputusan menginap wisatawan di De Vins Sky Hotel dengan nilai F hitung 19,667 $>\mathrm{F}$ ta bel $(3,94)$ dan nilai sig. $0,000<0,05$ yang berarti berpengaruh secara simultan sehingga bila variabel X (Online Review) naik atau berpengaruh dalam satu satuan, maka variabel $Y$ (Keputusan Menginap) akan mengalami kenaikan atau terpenuhi. Kesimpulannya secara garis besar ialah bahwa online review berpengaruh positif dan signifikan terhadap keputusan menginap wisatawan di De Vins Sky hotel denga $\mathrm{n}$ fasilitas sub variabel y ang paling signifikan pengaruhnya.
\end{abstract}

Kata Kunci : Online Review, Booking.com, Keputusan Menginap.

\begin{abstract}
On the site for online review there are some elements that are often read, namely information about the object sought, products presented in the form of reviews, photos, places and facilities downloaded on the page which will influence the decision to stay at a hotel. The purpose of this study was to determine the effect of an online review market (general information, reviews, photos, location, and facilities) on the booking.com site on tra velers' decisions to stay at De Vins Sky Hotel, Seminyak. To find out the most significant variable influencing tourist decisions to stay at De Vins Sky Hotel, Seminyak. The way to collect data is through observation, questionnaires and litera ture study. The research method used in this research is Descriptive Statistical Analysis with Likert scale calculation, and Inferential Statistical Analy sis consisting of correlation analysis, Multiple Linear Analysis, Simultaneous Analysis (F Test), Partial Analy sis (T test), Determination Analysis. The results showed that there was a positive and significant influence from the Online Review on Booking.com on travelers' decision to stay at De Vins Sky Hotel with an F value of 19.667> F table (3.94) and sig. 0,000<0.05, which means that the effect simultaneously so if the $\mathrm{X}$ variable (Online Review) increases or influences in one unit, then the variable $\mathrm{Y}$ (Decision Overnight) will increase or be fulfilled. The conclusion in outline is that tonline review hasa positive and significant effect on travelers' decision to stay at De Vins Sky hotel with the most significant sub-variable facilities.
\end{abstract}

Keywords : Online Review, Booking.com, Decision to Stay.

\section{PENDAHULUAN}

Bali telah menjadi salah satu daerah tujuan wisata dunia yang sangat popular. Pariwisata merupakan sumber perekonomian sebagian besar masyarakat Bali. Hal itu dilihat dari adanya berbagai macam fasilitas yang mendukung akitivatas pariwisata baik secara langsung maupun tidak langsung 
seperti hotel, restaurant, pusat hiburan, pusat perbelanjaan, transportasi, jasa angkutan, atraksi wisata, serta biro perjalanan wisata. Berikut merupakan jumlah kunjungan wisatawan yang datang ke Bali dapat dilihat pada Tabel 1 di bawah ini :

Tabel 1: Jumlah Kunjungan Wisatawan ke Bali Tahun 2013 - 2018

\begin{tabular}{ccccc}
\hline \multirow{2}{*}{ Tahun } & \multicolumn{2}{c}{ Jumlah Wisatawan } & $\begin{array}{c}\text { Jumlah } \\
\text { (orang) }\end{array}$ & $\begin{array}{c}\text { Pertumbuhan } \\
(\%)\end{array}$ \\
\cline { 2 - 3 } & Asing & Domestik & 10.255 .134 & 0 \\
\hline 2013 & 3.278 .598 & 6.976 .536 & 10.159 .098 & $-0,94$ \\
\hline 2014 & 3.766 .638 & 6.392 .460 & 11.148 .935 & 9,74 \\
\hline 2015 & 4.001 .835 & 7.147 .100 & 13.572 .617 & 21,74 \\
\hline 2016 & 4.927 .937 & 8.643 .680 & 14.433 .372 & 6,34 \\
\hline 2018 & 5.697 .739 & 8.735 .633 & 15.828 .464 & 9,66 \\
\hline Jumlah & 6.070 .473 & 9.757 .991 & 69.924 .661 & 46,54 \\
\hline Rata - Rata & 24.937 .500 & 44.986 .172 & 11.654 .110 & \\
\hline Sunnnnnn & 4.156 .250 & 7.497 .695 & & \\
\hline
\end{tabular}

*Sumber: Badan Pusat Statistik (2018).

Berdasarkan Tabel 1 dapat dilihat bahwa jumlah wisatawan yang datang ke Bali dari tahun 2013 sampai 2018 sempat mengalami penurunan di tahun 2014 khususnya pada wisatawan domestik namun setelah itu setiap tahunnya mengalami peningkatan yang cukup tinggi hal itu terjadi pada tahun 2015 2016, pada tahun 2015 wisatawan yang berkunjung ke Bali sejumlah 11.148.935 jiwa, namun pada tahun 2016 wisatawan yang berkunjung ke Bali mengalami peningkatan yang signifikan dengan presentase $21,7 \%$ dimana saat tahun 2016 jumlah wisatawan yang berkunjung 13.527.197 jiwa sekitar 2.423.682 kunjungan wisatawan yang bertambah. Media yang digunakan untuk mempromosikan hotel salah satunya media online. Perkembangan internet adalah faktor pendorong perkembangan e-commerce. Internet merupakan jaringan global yang menyatukan jaringan komputer di seluruh dunia yang memungkinkan terjalinnya komunikasi dan interaksi antara satu dengan yang lain di seluruh dunia. Penggunaan media internet dalam rangka memasarkan suatu barang atau jasa menjadi semakin marak mengingat potensi yang diberikan e-commerce sangatlah membantu pemasaran suatu hotel. Potensi yang dimaksud ialah segmen pasar yang semakin luas dan informasi tentang produk yang bisa diakses konsumen selama 24 jam. Dengan melakukan bisnis secara elektronik perusahaan dapat menekan biaya yang harus dikeluarkan untuk keperluan pengiriman informasi. Proses transaksi yang berlangsung secara cepat juga mengakibatkan meningkatnya produktivitas perusahaan. Informasi merupakan bagian terpenting dari suatu e-commerce. De Vins Sky juga melakukan promosi dengan bekerjasama dengan beberapa OTA yang sebelumnya sudah dijelaskan diawal OTA yang diajak bekerjasama yaitu Booking.com, Agoda.com, Traveloka.com, Pegi-pegi, Tiket.com dan masih banyak lagi lainnya. Keuntungan De Vins Sky Hotel bekerjasama dengan online travel agent ialah dapat lebih dikenal oleh tamu-tamu yang lainnya sehingga menambah penjualan kamar secara tidak langsung.

Di online travel agent memungkinkan setiap orang untuk berbagi pengalaman, dan memberikan tips mengenai perjalanan mereka. Setiap orang bebas memberikan tanggapan dan ulasan berdasarkan pengalaman yang mereka alami selama menginap di akomodasi pilihan mereka, baik berupa ulasan positif maupun negatif. Ulasan-ulasan ini dapat memberikan pengaruh terhadap citra dan merek hotel itu sendiri. Online Travel Agent digunakan oleh De Vins Sky Hotel sebagai sarana promosi yang efektif. 
Online Travel Agent sangatlah penting bagi De Vins Sky Hotel dan menjadi salah satu nilai objektif untuk "Achievement Programs". Berikut dapat dilihat pada Tabel 2 mengenai jumlah tamu yang melakukan reservasi online maupun offline melalui telepon atau Guest Walk in di De Vins Sky Hotel pada tahun 2014-2018.

Tabel 2: Jumlah Tamu yang Melakukan Reservasi Kamar di De Vins Sky Hotel Tahun 2014-2018

\begin{tabular}{|c|c|c|c|c|c|c|c|c|c|}
\hline \multirow[b]{2}{*}{ Th } & \multicolumn{7}{|c|}{ Reservasi(Jiwa) } & \multirow[b]{2}{*}{ Jumlah } & \multirow{2}{*}{$\begin{array}{c}\text { Pertumbu } \\
\operatorname{han}(\%)\end{array}$} \\
\hline & $\begin{array}{l}\text { Booking } \\
\text {.com }\end{array}$ & Expedia & Agoda & $\begin{array}{c}\text { Travelok } \\
a\end{array}$ & $\begin{array}{c}\text { Lainny } \\
\quad a\end{array}$ & Ofline & $\begin{array}{c}\text { Langsun } \\
\mathrm{g}\end{array}$ & & \\
\hline 2014 & 5.174 & 1.586 & 918 & 417 & 250 & 11.457 & 9.933 & 29.735 & - \\
\hline 2015 & 8.890 & 3.334 & 2.064 & 1.111 & 476 & 12.042 & 9.630 & 37.547 & 26,27 \\
\hline 2016 & 24.225 & 8.945 & 2.982 & 745 & 372 & 15.443 & 11.307 & 64.019 & 70,50 \\
\hline 2017 & 23.704 & 8.839 & 3.616 & 3.214 & 803 & 17.564 & 10.721 & 68.461 & 6,94 \\
\hline 2018 & 23.207 & 7.736 & 5.028 & 1.547 & 1.160 & 19.788 & 9.414 & 67.880 & $-0,85$ \\
\hline Jmlh & 85.200 & 30.440 & 14.608 & 7.034 & 3.061 & 76.294 & 51.005 & 267.642 & \\
\hline
\end{tabular}

*Sumber: De Vins Sky Hotel(2019).

Pada Tabel 2 terlihat reservasi tertinggi ada pada tahun 2017 dengan jumlah 68.461 reservasi dan reservasi terendah ada pada tahun 2014 hal ini disebabkan karena De Vins Sky Hotel baru saja dibuka dan belum banyak yang mengetahui hotel tersebut. Dapat dilihat juga reservasi online tertinggi ada pada situs booking.com dengan jumlah 85.200 reservasi selama empat tahun tersebut dengan reservasi tertinggi untuk booking.com terjadi pada tahun 2016 dengan jumlah reservasi 24.225 dan terendah terjadi pada tahun 2014 dengan jumlah 5.174 reservasi.

Booking.com merupakan salah satu online travel agent tebesar di dunia, komunitas wisata yang digunakan untuk mencari informasi, saran, dan opini dari jutaan wisatawan guna membantu dalam merencanakan perjalanan yang diimpikan. Komunitas ini berisikan percakapan yang jujur di antara wisatawan - wisatawan yang ada di dunia. Booking.com didirikan pada tahun 1996 di Amsterdam, Booking.com telah berkembang dari startup kecil Belanda menjadi salah satu perusahaan e-commerce perjalanan terbesar di dunia. Bagian dari Booking Holdings Inc. (NASDAQ: BKNG), Booking.com sekarang memperkerjakan lebih dari 17.000 karyawan di 198 kantor di 70 negara seluruh dunia. Situs ini juga merupakan situs perjalanan yang memungkinkan setiap orang untuk mengekspresikan diri, berbagi pengalaman, dan memberikan tips mengenai perjalanan mereka. De Vins Sky Hotel melakukan kerjasama dengan booking.com dimulai Juni tahun 2014 bentuk kerjasama yang dilakukan hotel De Vins Sky dengan booking.com ialah membantu dalam memasarkan kamar maksudnya untuk harga dan ketersedian kamar tetap di kendalikan oleh pihak hotel, booking.com hanya menampilkan sesuai dengan apa yang telah diberikan oleh pihak hotel pada situsnya namun ketika ada reservasi yang dilakukan dari tamu melalui booking.com maka pihak hotel akan membayar berupa komisi kepada pihak booking.com sesuai dengan kontrak yang sebelumnya telah disepakati oleh dua belah pihak. Pada situs booking.com khususnya untuk property De Vins Sky Hotel dapat dilihat mengenai informasi dan ulasan - ulasan dari tamu yang sebelumnya sudah pernah menginap di De Vins Sky.

Unsur - unsur yang terdapat dalam situs Online Review antara lain informasi foto pendukung dari wisatawan, tarif kamar, ulasan dari wisatawan, foto kamar dan fasilitas yang dimiliki, informasi lokasi jarak bandara dari hotel dan tempat hiburan dan destinasi di dekat hotel dan tanya jawab dengan manajemen hotel. Semua komponen unsur selalu diperhatikan oleh pihak manajemen hotel karena hal itu berkaitan dengan citra dan kualitas yang dimiliki De Vins Sky Hotel. Hal ini yang dapat 
mempengaruhi wisatawan untuk menentukan keputusan menginap, akan tetapi ada satu variabel pada online review ini yang paling mempengaruhi wisatawan untuk menentukan keputusan menginap di De Vins Sky Hotel. Oleh karena itu, maka perlu dilakukan sebuah penelitian mengenai masalah ini. Didukung oleh fenomena dan data dari uraian latar belakang di atas penulis tertarik melakukan penelitian mengenai "Pengaruh Online Review pada Booking.com Terhadap Keputusan Wisatawan Menginap di De Vins Sky Hotel, Seminyak”. Berdasarkan latar belakang tersebut, maka rumusan masalah yang ada dalam penelitian ini adalah Bagaimana pengaruh pasar online review (informasi umum, ulasan, foto, lokasi, dan fasilitas) pada situs booking.com terhadap keputusan wisatawan menginap di De Vins Sky Hotel, Seminyak? Variabel manakah yang paling signifikan berpengaruh terhadap keputusan menginap wisatawan di De Vins Sky Hotel, Seminyak.

Adapun tujuan dari penelitian ini adalah Untuk mengetahui pengaruh pasar online review (informasi umum, ulasan, foto, lokasi, dan fasilitas) pada situs booking.com terhadap keputusan wisatawan menginap di De Vins Sky Hotel, Seminyak, Untuk mengetahui variabel yang paling signifikan berpengaruh terhadap keputusan wisatawan menginap di De Vins Sky Hotel, Seminyak

Hasil penelitian sebelumnya yang digunakan sebagai rujukan guna untuk melengkapi penelitian ini adalah penelitian Amalia (2013) dengan judul "Analisis Pengaruh Pemanfaatan Situs TripAdvisor terhadap Keputusan Pembelian Kamar Hotel di Kota Bandung sebagai Destinasi Wisata". Tujuan dari penelitian ini adalah untuk menganalisis tingkat pemanfaatan situs TripAdvisor, menganalisis tingkat keputusan pembelia kamar hotel, dan menganalisis pengaruh pemanfaatan situs TripAdvisor terhadap keputusan pembelian kamar hotel. Teknik pengumpulan data yang digunakan adalah kuesioer. Teknik analisis data yang digunakan adalah metode deskriptif melalui pendekatan kuantitatif dengan maksud untuk mengetahui gambaran dan tanggapan dari sebagian populasi yang menjadi objek penelitian terhadap Pemanfaatan Situs TripAdvisor dan Keputusan Pembelian Kamar Hotel. Dalam proses analisisnya digunakan analisis regresi linear sederhana. Hasil penelitian ini menunjukkan bahwa pemanfaatan situs TripAdvisor memperoleh kategori tinggi. Selanjutnya, keputusan pembelian kamar hotel juga berada dalam kategori tinggi. Untuk pengaruh pemanfaatan situs TripAdvisor terhadap keputusan pembelian kamar hotel sebesar 0,531 yang artinya hubunganya sedang. Sedangkan untuk perhitungan koefisien regresi, diperoleh persamaan regresi sebagai berikut $\mathrm{Y}=33,640+0,445 \mathrm{X}$ bahwa semakin baik pemanfaatan situs TripAdvisor maka semakin baik pula keputusan pembelian kamar hotel dan juga sebaliknya. Selanjutnya koefisien determinasi yang diperloleh 28,20 persen, dengan kata lain pengaruh pemanfaatan situs TripAdvisor terhadap keputusan pembelian kamar hotel sebesar 28,20 persen atau 71,80 persen dipengaruhi oleh factor lainnya. Persamaan penelitian ini dengan yang sekarang adalah sama - sama meneliti tentang keputusan pembelian dan mengunakan teknik pegumpulan data berupa kuesioner dan menggunakan metode deskriptif melalui pendekatan kuantitatif. Perbedaannya terletak pada lokasi dan waktu penelitian.

Penelitian kedua yang dijadikan rujukan yaitu penelitian yang dilakukan Wati (2015), yang berjudul "Analisis Pengaruh Online Review dalam TripAdvisor terhadap Keputusan Menginap Wisatawan di Hotel Centra Taum Seminyak Badung, Bali”. Tujuan dari penelitian ini untuk mengetahui persepsi wisatawan terhadap online review dalam tripadvisor mengenai Hotel Centra Taum Seminyak dan mengetahui pengaruh online review dalam tripadvisor terhadapa keputusan menginap wisatawan di hotel Centra Taum Seminyak. Teknik pengumpulan data yang digunakan dengan observasi, wawancara, kuesioner, dan studi kepustakaan. Teknik analisis data yang digunakan ialah metode analisis kuantitatif yang didukung dengan analisis kualitatif, antara lain : dengan menggunakan skala likert untuk menganalisis kuesioner, uji validitas, uji reliabilitas, analisis korelasi, analisis regresi berganda, uji f, uji $\mathrm{t}$, dan analisis determinasi. Hasil penelitian menunjukan bahwa responden sangat setuju terhadap pengalaman yang mereka peroleh dengan ekspetasi saat mereka membaca online review dalam tripadvisor. Unsur nama dan alamat hotel memiliki nilai rata-rata tertinggi yaitu 4.70 yang juga berarti sangat setuju sedangkan fasilitas dan lokasi memiliki nilai rata-rata terendah diantara seluruh indikator yang disebabkan kurangnya petunjuk jalan menuju hotel dan letak kamar yang cukup jauh dari lobby. Variabel fasilitas tidak memiliki signifikan secara bersama terhadap keputusan menginap karenat hitung 


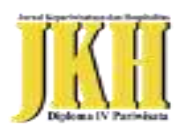

JURNAL KEPARIWIS ATAAN DAN HOSPITALITAS

Vol. 4, No. 2, November 2020.

lebih kecil daripada t tabel, sedangkan indikator yang lain seperti nama dan alamat hotel, ulasan, foto, lokasi, tips kamar, tanya jawab dan tampilan harga memiliki pengaruh yang signifikan terhadap keputusan menginap. 98,4\% keputusan menginap (Y) dapat dijelaskan oleh indikator-indikator variabel online review $(\mathrm{X})$. Persamaan penelitian ini dengan penelitian yang sekarang yaitu sama - sama meneliti tentang $\mathrm{E}$ - Commerce yang bergerak di bidang perjalanan, meneliti tentang keputusan menginap wisatawan dan menggunakan teknik penumpulan data yang sama yaitu observasi, wawancara, kuesioner, dan studi kepustakaan; sama - sama menggunakan teknik analisis data berupa analisis data kuantitatif yang didukung dengan analisis kualitatif, menggunakan skala likert untuk menganalisis kuesioner dan menggunakan uji validitas, uji reliabilitas. Perbedaannya ada pada lokasi penelitian, waktu penelitian.

Penelitian yang ketiga dilakukan oleh Lestari (2017), dengan judul "Analisis Pengaruh Situs TripAdvisor terhadap Keputusan Menginap Wisatawan di Pullman Bali Legian Nirwana Hotel and Resort". Adapun metode penelitian yang digunakan pada penelitian ini deskriptif kualitatif dengan alat bantu skala likert dan analisis kuantitatif, serta dengan uji validitas, uji reliabilitas, analisis korelasi, analisis regresi berganda, uji f dan uji t. Hasil penelitian menunjukan bahwa terjadi hubungan yang kuat antara variabel situs TripAdivisor (X) terhadap variabel Keputusan menginap (Y). Nilai korelasi berganda (R) yang didapat sebesar 0,621. Informasi umum (X1), tips kamar (X2), tarif (X3), ulasan (X4), foto (X5), informasi lokasi (X6), fasilitas (X7), dan tanya jawab (X8) secara bersama - sama berpengaruh terhadap keputusan menginap (Y) karena F hitung > dari F tabel $(7,144>2,04)$. Informasi umum (X1), tips kamar (X2), tarif (X3), foto (X5), informasi lokasi (X6), fasilitas (X7), dan tanya jawab (X8) secara parsial tidak berpengaruh signifikan terhadap keputusan menginap $(\mathrm{Y})$ karena nilai $-\mathrm{t}$ tabel $\mathrm{t}$ hitung $\mathrm{t}$ tabel. Satu - satunya unsur dalam situs TripAdvisor yang paling berpengaruh signifikan terhadap keputusan menginap wisatawan di Pullman Bali Legian Nirwana Hotel and Resort adalah unsur ulasan, dengan nilai $\mathrm{t}$ hitung $>\mathrm{t}$ tabel $(3,936>1,986)$ dan nilai signifikansi $<0,05(0,00<0,05)$. Persamaan penelitian ini dengan penelitian yang sekarang yaitu sama - sama meneliti tentang e- commerce yang bergerak di bidang perjalanan, meneliti tentang keputusan menginap wisatawan dan menggunakan teknik penumpulan data yang sama yaitu observasi, wawancara, kuesioner, dan studi kepustakaan, sama - sama menggunakan teknik analisis data berupa analisis data kuantitatif yang didukung dengan analisis kualitatif, menggunakan skala likert untuk menganalisis kuesioner dan menggunakan uji validitas, uji reliabilitas. Perbedaannya ada pada lokasi penelitian, waktu penelitian.

\section{METODE PENELITIAN}

Lokasi penelitian ini dilakukan di Hotel De Vins Sky. De Vins Sky merupakan hotel bintang empat (4) yaitu di jalan Jl. Komp. Villa Kendal, Petitenget no 35, Kabupaten Badung, Bali 80361, Indonesia. De Vins Sky Hotel terletak pinggiran keramaian kota seminyak, 30-menit berkendara dari bandara dan dekat dengan berbagai fasilitas wisata dan hiburan di seminyak, seperti Potato Head, seminyak Squaer. De Vins Sky memiliki 105 kamar yang nyaman, Blu Sky Restauran and Bar, kolam renang, spa, ruang olahraga, fasilitas pertemuan dan lounge gratis bagi mereka yang datang lebih awal dan berangkat pada malam hari.

Variabel - variabel yang digunakan untuk membatasi permasalahan yang akan dibahas dalam penelitian ini yaitu sebagai berikut :

1) Pengaruh Online Review (X)

Online Review yang dimaksud dalam penelitian ini adalah semua informasi yang dapat dilihat oleh calon konsumen pada online travel agent khususnya Booking.com yang diunduh atau dibuat oleh tamu yang pernah menginap di De Vins Sky Hotel. Informasi dalam hal ini fokus pada informasi terhadap akomodasi, yaitu De Vins Sky Hotel. Ada beberapa variabel dalam online review berdasarkan tinjauan pustaka yang disesuaikan dengan penelitian ini, dapat dilihat pada Tabel 3 di bawah ini :

Tabel 3. Indikator Variabel Online Review (X)

VariabelOnline Review Indikator Sumber




\begin{tabular}{|c|c|c|}
\hline $\begin{array}{c}\text { Informasi Umum (X1) } \\
\text { (Cunningham dan a wan } \\
\text { - kawan, 2010) } \\
\text { (Vermuelen dan Daphne } \\
\text { Seegers, 2009) }\end{array}$ & $\begin{array}{l}\text { 1) Nama, a lamat, dan } \\
\text { nomor telepon yang } \\
\text { dapatdihubungi dan } \\
\text { ditampilkan dengan } \\
\text { jelas } \\
\text { 2) Link website yang } \\
\text { tercantum jelas dan } \\
\text { dapatdiakses }\end{array}$ & \\
\hline $\begin{array}{l}\text { Ula san atau review (X2) } \\
\text { (Mudambi, Susan dan } \\
\text { Da vid Scuff, 2010) } \\
\text { (Vermuelen dan Da phne } \\
\text { Seegers, 2009) }\end{array}$ & $\begin{array}{l}\text { 1) } \begin{array}{l}\text { Situs menampilkan } \\
\text { banyak ulasan }\end{array} \\
\text { positif mengenai } \\
\text { Hotel } \\
\text { 2) Kesesuaianulasan } \\
\text { terhadappelayanan } \\
\text { yang diterima di } \\
\text { hotel } \\
\text { 3) Respon yang baik } \\
\text { daripihak } \\
\text { manajemen hotel } \\
\text { terhadapulasan }\end{array}$ & \\
\hline $\begin{array}{c}\text { Foto (X3) } \\
\text { (Miguens dan kawan- } \\
\text { kawan, 2008) } \\
\text { (Vermuelen dan Da phne } \\
\text { Seegers, 2009) }\end{array}$ & $\begin{array}{l}\text { 1) Foto interior hotel } \\
\text { (ka mar, lobi, dan } \\
\text { ruangan lainnya) } \\
\text { terlihat rapi dan } \\
\text { menarik. } \\
\text { 2) Foto sesuai dengan } \\
\text { kenyataan }\end{array}$ & $\begin{array}{l}\text { Wati(2015:14) } \\
\text { Booking.com }\end{array}$ \\
\hline $\begin{array}{c}\text { Loka si (X4) } \\
\text { (Vermuelen dan Daphne } \\
\text { Seegers, 2009) }\end{array}$ & $\begin{array}{l}\text { 1) Lokasi mudah } \\
\text { dijangkau } \\
\text { 2) Lokasi dapat dilihat } \\
\text { mela lui peta } \\
\text { 3) Loka si dekat dengan } \\
\text { fasilita s pendukung } \\
\text { jasa seperti restoran, } \\
\text { bardan a traksi } \\
\text { wisata }\end{array}$ & \\
\hline $\begin{array}{c}\text { Fa silitas (X5) } \\
\text { (Vermuelen dan Daphne } \\
\text { Seegers, 2009) }\end{array}$ & $\begin{array}{l}\text { 1) Fa silitas yang } \\
\text { tersedia bemacam- } \\
\text { ma cam } \\
\text { 2) Fa silita s yang ra pi, } \\
\text { bersih, dan nyaman } \\
\text { saat digunakan } \\
\text { 3) Fa silitas yang } \\
\text { tersedia sesuai } \\
\text { dengan kebutuhan } \\
\text { wisata wan }\end{array}$ & \\
\hline
\end{tabular}

* Sumber: Data Penelitian yang diolah (2018).

Jenis data yang digunakan ialah data kualitatif dan data kuantitatif. Sumber data menggunakan data primer dan data sekunder. Teknik pengumpulan data yang digunakan yaitu observasi, kuesioner, dan studi kepustakaan dan dokumentasi. Teknik Penentuan Sampel dengan probability sampling, penentuan pengambilan sampel dilakuan secara accidental dengan jumlah 100 wisatawan pada booking.com. Teknik Analisis Data yang digunakan Analisis Statistik Deskriptif yaitu analisis skala 
likert dan Analisis Statistik Inferensial yaitu Analisis Korelasi, Analisis Regresi Linear Berganda, Analisis Simultan Uji F, Analisis Parsial Uji t (Uji Hipotesis), Analisis Determinasi.

Indikator - indikator dalam penelitian ini diukur dengan skala likert yang memiliki lima tingkat preferensi jawaban yang masing - masing mempunyai skor $1-5$ dengan rincian sebagai berikut :

$1=$ Sangat tidak setuju

2 = tidak setuju

$3=$ ragu - ragu atau netral

$4=$ setuju

$5=$ sangat setuju

Untuk mengetahui intensitas persepsi wisatawan terhadap online review pada hotel, dengan mencari terlebih dahulu rentang nilainya dengan rumus di bawah ini:

Skor tertinggi - skor terendah $=$ rentang/interval

Jumlah kelas

$\frac{5-1}{5}=0,80$

Berdasarkan rumus tersebut di atas, ini berarti bahwa masing - masing kategori memiliki rentang nilai (interval) sebesar 0,8 . Hal ini dapat dilihat pada nilai rata-rata berikut:

4,24-5,00 : kategori sangat setuju.

$3,43-4,23$ : kategori setuju.

$2,62-3,42$ : kategori netral.

$1,81-2,61$ : kategori tidak setuju.

$1,00-1,80$ : kategori sangat tidak setuju.

Beberapa analisis lainnya yang digunakan untuk menguji kelayakan dari pernyataan pada kuesioner yaitu uji validitas dan uji reliabilitas serta uji asumsi klasik.

\section{HASIL DAN PEMBAHASAN}

Uji validitas akan menguji masing - masing variabel yang digunakan dalam penelitian ini, keseluruhan variabel penelitian memuat 17 pernyataan yang harus dijawab oleh responden. Adapun kriteria yang digunakan dalam menentukan valid tidaknya pernyataan yang digunakan dalam penelitian ini adalah sebagai berikut: $(\alpha=0,05)$, derajat kebebasan $(\mathrm{df})=\mathrm{n}-\mathrm{k}=100-6=94$, maka di dapat $\mathrm{r}$ tabel $=0.1966$.

Berdasarkan analisis yang telah dilakukan, maka hasil pengujian validitasnya dapat ditunjukan pada Tabel 4 sebagai berikut :

Tabel4. Hasil Uji Validitas

\begin{tabular}{ccccc}
\hline $\begin{array}{c}\text { Indikator } \\
\text { Variabel }\end{array}$ & Item Pernyataan & $\mathbf{r}_{\text {hitung }}$ & $\mathbf{r}_{\text {tabel }}$ & Keterangan \\
\hline $\begin{array}{c}\text { Informasi Umum } \\
(\mathrm{X} 1)\end{array}$ & 1 & 0.854 & 0.2006 & Valid \\
\cline { 2 - 5 } & 2 & 0.879 & 0.2006 & Valid \\
\hline Ula san atau \\
\cline { 2 - 5 } Review (X2) & 1 & 0.756 & 0.2006 & Valid \\
\cline { 2 - 5 } & 2 & 0.728 & 0.2006 & Valid \\
\hline
\end{tabular}




\begin{tabular}{ccccc}
\hline \multirow{2}{*}{ Foto (X3) } & 1 & 0.850 & 0.2006 & Valid \\
\cline { 2 - 5 } & 2 & 0.866 & 0.2006 & Valid \\
\hline \multirow{3}{*}{ Lokasi (X4) } & 1 & 0.732 & 0.2006 & Valid \\
\cline { 2 - 5 } & 2 & 0.801 & 0.2006 & Valid \\
\cline { 2 - 5 } & 3 & 0.810 & 0.2006 & Valid \\
\cline { 2 - 5 } Fasilitas (X5) & 1 & 0.703 & 0.2006 & Valid \\
\cline { 2 - 5 } & 2 & 0.812 & 0.2006 & Valid \\
\hline \multirow{2}{*}{$\begin{array}{c}\text { Keputusan } \\
\text { Menginap (Y) }\end{array}$} & 1 & 0.824 & 0.2006 & Valid \\
\cline { 2 - 5 } & 2 & 0.698 & 0.2006 & Valid \\
\cline { 2 - 5 } & 3 & 0.796 & 0.2006 & Valid \\
\cline { 2 - 5 } & 4 & 0.712 & 0.2006 & Valid \\
\hline
\end{tabular}

* Sumber: Data Kuesioner yang diolah (2019).

Berdasarkan Tabel 4.6 dapat diketahui bahwa nilai dari r hitung keseluruhan indikator yang diuji bernilai positif dan lebih besar dari nilair tabel(0.1966). Maka dari itu dapat disimpulkan, bahwa seluruh indikator yang digunakan dalam penelitian ini lolos da la m uji validitas dan dinyatakan valid.

Uji reliabilitas digunakan untuk mengukur konsitensi konstruk atau variabel penelitian. Untuk mengukur uji relia bilitas dilakukan dengan menggunakan uji sta tistik Cronbach Alpha $(\alpha)$. Ada banyak cara untuk mengukur uji relia bilita s tersebut namun pada penelitian ini sua tu variabel dikatakan relia ble jika memberikan nila i koefisien Alpha lebih besar daripada 0,60 (Ghozali, 2005). Hasil uji reliabilitas dalam penelitian ini da pat dilihat pada Tabel 5 .

Tabel5. Hasil Uji Reliabilitas

\begin{tabular}{lccc}
\hline \multicolumn{1}{c}{ Variabel Penelitian } & Cronbach Alpha & Cut of Value & Keterangan \\
\hline Informasi Umum (X1) & 0,668 & 0,60 & Reliabel \\
\hline Ulasan atau Review (X2) & 0,622 & 0,60 & Reliabel \\
\hline Foto (X3) & 0,641 & 0,60 & Reliabel \\
\hline Loka si (X4) & 0,678 & 0,60 & Reliabel \\
\hline Fasilitas (X5) & 0,680 & 0,60 & Reliabel \\
\hline Keputusan Pembelian (Y) & 0,725 & 0,60 & Reliabel \\
\hline
\end{tabular}

* Sumber: Data Kuesioner yang diolah (2019).

Hasil pengujian reliabilitas pada Tabel 5 tersebut menunjukkan bahwa nilai koefisien Alpha dari variabel - variabel yang di teliti menunjukan hasil yang beragam. Akan tetapi, semua item pernyataan variabel $(\mathrm{X})$ dan variabel Y tersebut memiliki nilai koefisien alpha lebih besar daripada 0,60. Dengan demikian dapat disimpulkan bahwa alat ukur yang digunakan dalam penelitian ini adalah reliable. Adapun masing - masing nilai sub variabel $\mathrm{X}$ dan variabel $\mathrm{Y}$ ialah untuk informasi umum dengan nlai alpha 0.668 , untuk ulasan atau review dengan nilai alpha 0.622 , foto dengan nilai alpha 0.641 , lokasi 0.678, fasilitas 0,680 dan untuk keputusan menginap dengan nilai alpha 0.725 . 
Uji normalitas berguna untuk menguji apakah dalam model regresi, variabel dependen dan variabel independen memiliki distribusi normal atau tidak. Uji normalitas pada penelitian ini menggunakan distribusi pada grafik P-P plot. Berikut ini hasil uji normalitas menggunakan grafik P-P Plot menggunakan bantuan aplikasi SPSS versi 25

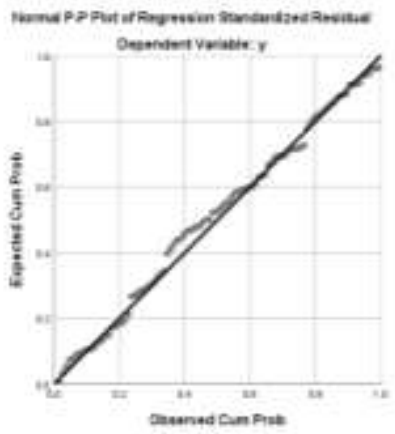

Gambar 1.Grafik P-PPlot

Dari Gambar 1 di atas dapat dilihat bahwa data menyebar disekitargaris diagonal dan mengikuti arah garis diagonal pada grafik histogram, hal ini menunjukkan bahwa pola distribusi normal. Jadi dapat disimpulkan bahwa berdasarkan grafik P-P plot, model regresi memenuhi asumsi normalitas.

Uji heteroskedastisitas bertujuan untuk menguji dalam model regresi terjadi ketidaksamaan varians dari residual satu pengamatan ke pengamatan yang lain. Cara untuk mengetahui terjadi heteroskedastisitas atau tidak yaitu dengan melihat Grafik Plot antara nilai prediksi variabel dependen yaitu ZPRED dengan residualnya SRESID. Tidak terjadi heteroskedastisitas yaitu apabila tidak ada pola yang jelas, serta titik-titik menyebar di atas dan di bawah angka 0 pada sumbu Y. Berikut hasil uji heteroskedastisitas dengan bantuan SPSS versi 25 disajikan dalam bentuk grafik Scatterplot.

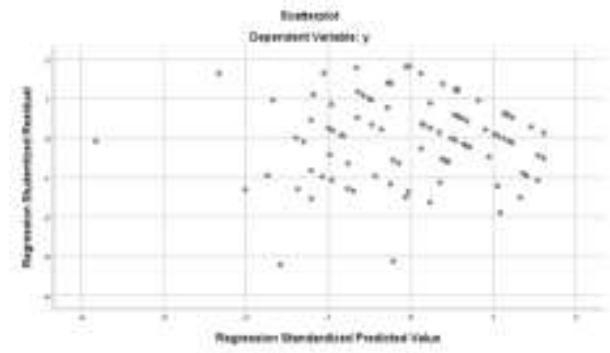

Gambar 2. Grafik Scatterplot

Dari Gambar 4.16 dapat dilihat bahwa titik - titik yang menyebar tidak membentuk sebuah pola dan titik - titik yang ada tersebar di atas dan di bawah angka 0 pada sumbu $\mathrm{Y}$, hal ini menunjukkan bahwa data dalam penelitian ini tidak terjadi heteroskedastisitas.

Uji Multikolinieritas berguna untuk menguji apakah model regresi ditemukan adanya korelasi antar variabel independen. Cara mengetahui ada tidaknya penyimpangan uji multikolinieritas adalah dengan melihat nilai Tolerance dan VIF masing-masing variabel independen, jika nilai Tolerance $>0.10$ dan nilai $\mathrm{VIF} \leq 10$, maka data bebas dari gejala multikolinieritas.

\section{Coefficients $^{\mathrm{a}}$}




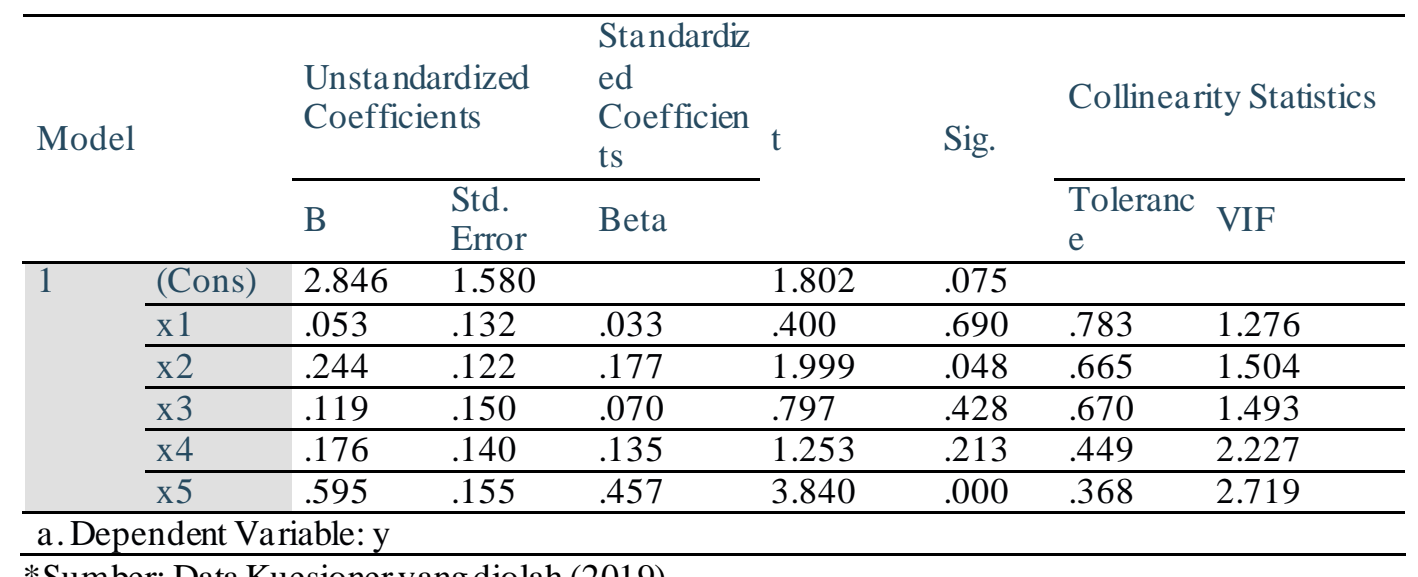

*Sumber: Data Kuesionery yang diolah (2019).

Melihat hasil pada Tabel6, hasil perhitungan nilai Tolerance pada setia p variabel independen memiliki nilai Tolerance lebih dari 0.10 dengan nilai Tolerance masing-masing variabel independen yaitu untuk informasi umum (X1) sebesar 0.783, online review (X2) sebesar 0.665, foto (X3) sebesar 0.670, lokasi (X4) sebesar 0.449 dan fa silitas (X5) sebesar 0.368. Sementara itu hasil perhitungan nilai Variance Inflation Factor (VIF) menunjukkan nilai VIF dari setiap varia bel independen kurang dari 10 dengan nilai VIF masing-masing variabel independen bernilai informasi umum (X1) sebesar 1.276, on line review (X2) sebesar 1.504, foto (X3) sebesar 1.493, lokasi (X4) sebesar 2.227 dan fasilitas (X5) sebesar 2.719. Merujuk hasil perhitungan nilai Tolerance dan VIF dapat disimpulkan bahwa tidak ada multikolinieritas a ntar variabel independen dalam model regresi.

Skala likert digunakan untuk mengukur persepsi wisa tawan yang menginap di De Vins Sky hotel terhadap online review yang a da pada booking.com mengenai De Vins Sky Hotel sehingga tamu dapat melakukan keputusan untuk menginap di De Vins Sky Hotel. Pada booking.com terdapat beberapa unsur yang menjadi indikator penentuan persepsi wisata wan yang dijabarkan melalui kuesioner yang diisi 100 responden yang dimana merupakan tamu De Vins Sky hotel khususnya yang pernah memanfaatkan media online berupa booking.com. Penjelasan dari tia $\mathrm{p}$ - tiap indikator yang merupakan bagian dari variabel X dapat dilihat pada Tabel 7 di bawah ini.

Tabel7. Hasil Perhitungan Skala Likert

\begin{tabular}{|c|c|c|c|c|c|c|c|c|c|c|}
\hline No & VariabelX & Indikator & SS & S & $\mathrm{N}$ & $\mathrm{TS}$ & STS & Total & $\begin{array}{l}\text { Rata } \\
- \\
\text { Rata }\end{array}$ & Ket \\
\hline \multirow[t]{3}{*}{1} & \multirow[t]{2}{*}{$\begin{array}{l}\text { Informasi } \\
\text { Umum (X1) }\end{array}$} & $\begin{array}{l}\text { Nama, } \\
\text { a la mat dan } \\
\text { nomor } \\
\text { telepon hotel } \\
\text { yang dapat } \\
\text { dihubungi } \\
\text { dan } \\
\text { ditunjukan } \\
\text { denganjelas } \\
\text { pada } \\
\text { booking.com }\end{array}$ & 32 & 45 & 22 & 1 & - & 408 & 4,08 & S \\
\hline & & $\begin{array}{l}\text { Link website } \\
\text { dita mpilkan } \\
\text { denganjelas } \\
\text { dan dapat } \\
\text { diakses }\end{array}$ & 28 & 40 & 29 & 3 & - & 393 & 3,93 & S \\
\hline & Total & & & & & & & & $\begin{array}{l}4,01 \\
\end{array}$ & $\mathbf{S}$ \\
\hline 2 & $\begin{array}{l}\text { Ulasan atau } \\
\text { Review (X2) }\end{array}$ & $\begin{array}{l}\text { Banyaknya } \\
\text { ulasan }\end{array}$ & 25 & 47 & 28 & - & - & 397 & 3,97 & S \\
\hline
\end{tabular}




\begin{tabular}{|c|c|c|c|c|c|c|c|c|c|c|}
\hline & & $\begin{array}{l}\text { positif yang } \\
\text { muncul pada } \\
\text { booking.com } \\
\text { tentang De } \\
\text { Vins Sky } \\
\text { Hotel }\end{array}$ & & & & & & & & \\
\hline & & $\begin{array}{l}\text { Ulasan } \\
\text { sesuai } \\
\text { dengan } \\
\text { pelayanan } \\
\text { yangdi } \\
\text { dapat } \\
\end{array}$ & 43 & 45 & 11 & 1 & - & 430 & 4,30 & SS \\
\hline & & $\begin{array}{l}\text { Respon yang } \\
\text { baik dari } \\
\text { pihak } \\
\text { manajemen } \\
\text { hotel } \\
\text { terhadap } \\
\text { ulasan }\end{array}$ & 38 & 48 & 13 & 1 & - & 423 & 4,23 & $\mathrm{~S}$ \\
\hline & Total & & & & & & & & 4,17 & $\mathbf{S}$ \\
\hline \multirow[t]{3}{*}{3} & \multirow[t]{2}{*}{ Foto (X3) } & $\begin{array}{l}\text { Foto interior } \\
\text { hotel } \\
\text { (kamar, lobi, } \\
\text { dan ruangan } \\
\text { lainnya) } \\
\text { terlihat rapi } \\
\text { dan menarik. }\end{array}$ & 34 & 46 & 19 & 1 & - & 413 & 4,13 & $\mathrm{~S}$ \\
\hline & & $\begin{array}{l}\text { Foto sesuai } \\
\text { dengan } \\
\text { kenyataan }\end{array}$ & 41 & 38 & 20 & 1 & - & 419 & 4,19 & $\mathrm{~S}$ \\
\hline & Total & & & & & & & & 4,16 & $\mathbf{S}$ \\
\hline \multirow{4}{*}{4} & \multirow[b]{3}{*}{ Lokasi(X4) } & $\begin{array}{l}\text { Lokasi } \\
\text { mudah } \\
\text { dijangkau }\end{array}$ & 36 & 45 & 19 & - & - & 417 & 4,17 & $\mathrm{~S}$ \\
\hline & & $\begin{array}{l}\text { Loka si dapat } \\
\text { dilihat } \\
\text { melalui peta }\end{array}$ & 52 & 33 & 13 & 2 & - & 435 & 4,35 & SS \\
\hline & & $\begin{array}{l}\text { Loka sidekat } \\
\text { dengan } \\
\text { fasilitas } \\
\text { pendukung } \\
\text { jasa seperti } \\
\text { restoran, bar } \\
\text { dan a traksi } \\
\text { wisata }\end{array}$ & 46 & 44 & 9 & 1 & - & 435 & 4,35 & SS \\
\hline & Total & & & & & & & & 4,29 & $\mathbf{S S}$ \\
\hline \multirow[t]{2}{*}{5} & \multirow[t]{2}{*}{ Fasilitas (X5) } & $\begin{array}{l}\text { Fasilitas } \\
\text { yang } \\
\text { tersedia } \\
\text { bermacam- } \\
\text { macam }\end{array}$ & 33 & 53 & 14 & - & - & 419 & 4,19 & $\mathrm{~S}$ \\
\hline & & $\begin{array}{l}\text { Fasilita s } \\
\text { yang } \\
\text { dimiliki rapi, }\end{array}$ & 51 & 33 & 14 & 2 & - & 433 & 4,33 & SS \\
\hline
\end{tabular}




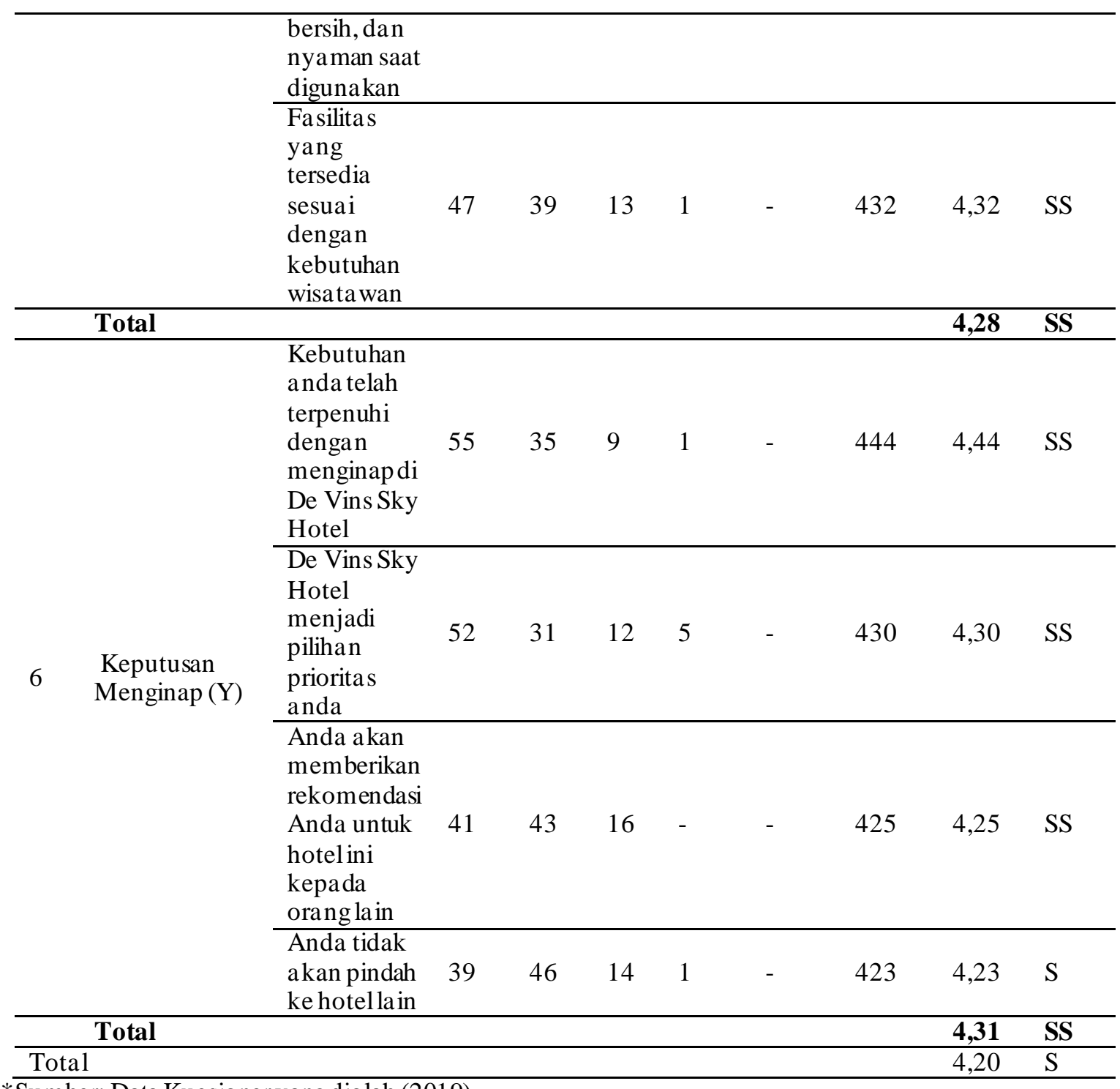

* Sumber: Data Kuesioner yang diolah (2019).

Dari Tabel 7 dapat disimpulkan bahwa rata - rata perepsi wisatawan yang menginap di De Vins Sky Hotel memberikan penilaian setuju dengan nilai rata - rata 4,20 untuk keseluruhan indicator online review pada booking.com yang dijadikan pengukuran pada penelitian ini. Hal ini menunjukan bahwa responden memberikan tanggapan positif terhadap online review yang ada pada booking.com dan membentuk persepsi yang positif juga pada De Vins Sky Hotel, Seminyak.

Informasi Umum (X1) memiliki nilai rata - rata yaitu 4,01, hal ini dikarenakan informasi yang di tampilkan pada situs booking.com dianggap sudah lengkap sehingga tamu atau wisatawan bisa mendapatkan informasi mengenai hotel dengan mudah. Ulasan atau review mendapatkan penilaian setuju dengan nilai rata - rata 4,17 mengenai review positif yang ada pada situs serta kesesuaian review terhadap pelayanan yang diterima, kesigapan manajemen hotel dalam merespon ulasan yang dibuat tamu atau wisatawan hal ini dibuktikan juga dengan beberapa ulasan positif yang dibuat oleh tamu sebelumnya yaitu Rhedell salah satu tamu yang berasal dari Australia memposting ulasan positifnya pada booking.com mengatakan "Loved my stay here! The staff and their service was amazing. The breakfast was really good and we thoroughly enjoyed the view as well while eating our delicious breakfast. Would recommend this stay for sure!" yang artinya "Saya senang menginap di sini! Staf dan layanan mereka 
sangat mengagumkan. Sarapannya sangat baik dan kami benar-benar menikmati pemandangan sambil makan sarapan lezat kami. Pasti tetap akan merekomendasikan ini!". Variabel Foto ini membahas tentang kesesuaian foto pada booking.com dengan kenyataan pada De Vins Sky Hotel, pada variabel ini mendapatkan respon setuju dengan rata - rata 4,16 hal ini dikarenakan foto memang sesuai dengan keadaan hotel tersebut. Variabel lokasi memiliki nilai rata - rata yaitu 4,29, hal ini dikarenakan lokasi yang mudah ditemukan baik itu dengan aplikasi maps, dan lokasi berada dekat dengan fasilitas penunjuang seperti yang sudah dijelaskan. Variabel fasilitas mendapatkan respon sangat setuju dengan nilai rata - rata 4,28 hal ini dikarenakan kesesuaian fasilitas dengan yang sudah di jelaskan pada booking.com. Untuk variabel keputusan menginap mendapatkan nilai rata - rata 4,31 dari hasil nilai rata - rata tersebut mendapatkan respon yang positif dari wisatawan untuk merekomendasikan De Vins Sky Hotel.

Analisis korelasi merupakan alat analisis untuk mengetahui ada tidaknya hubungan antara variabel X (Online Review) pada booking.com terhadap variabel Y (Keputusan Menginap) di De Vins Sky Hotel, Seminyak. Berikut hasil uji korelasi dengan menggunakan bantuan program SPSS versi 25 dapat dilihat pada Tabel 8 di bawah ini :

Tabel 8.HasilUjiKorelasi

\begin{tabular}{|c|c|c|c|c|c|c|c|}
\hline \multicolumn{8}{|c|}{ Correlations } \\
\hline & & $\begin{array}{l}\text { Informasi } \\
\text { umum }\end{array}$ & Ulasan & foto & Lokasi & fasilitas & $\begin{array}{l}\text { keputusan } \\
\text { menginap }\end{array}$ \\
\hline \multirow{3}{*}{$\begin{array}{l}\text { Informasi } \\
\text { umum }\end{array}$} & $\begin{array}{l}\text { Pearson } \\
\text { Correlation }\end{array}$ & 1 & $.436^{* *}$ & $.320^{* *}$ & $.197^{*}$ & $.231^{*}$ & $.264^{* *}$ \\
\hline & Sig. (2-tailed) & & .000 & .001 & .050 & .021 & .008 \\
\hline & $\mathrm{N}$ & 100 & 100 & 100 & 100 & 100 & 100 \\
\hline \multirow{3}{*}{ Ula san } & $\begin{array}{l}\text { Pearson } \\
\text { Correlation }\end{array}$ & $.436^{* *}$ & 1 & $.403^{* *}$ & $.366^{* *}$ & $.451^{* *}$ & $.475^{* * *}$ \\
\hline & Sig. (2-ta iled) & .000 & & .000 & .000 & .000 & .000 \\
\hline & $\mathrm{N}$ & 100 & 100 & 100 & 100 & 100 & 100 \\
\hline \multirow{3}{*}{ Foto } & $\begin{array}{c}\text { Pearson } \\
\text { Correlation }\end{array}$ & $.320^{* *}$ & $.403^{* *}$ & 1 & $.381^{* *}$ & $.523^{* *}$ & $.442^{* *}$ \\
\hline & Sig. (2-tailed) & .001 & .000 & & .000 & .000 & .000 \\
\hline & $\mathrm{N}$ & 100 & 100 & 100 & 100 & 100 & 100 \\
\hline \multirow[t]{3}{*}{ Lokasi } & $\begin{array}{l}\text { Pearson } \\
\text { Correlation }\end{array}$ & $.197^{*}$ & $.366^{* *}$ & $.381^{* *}$ & 1 & $.741^{* *}$ & $.571^{* *}$ \\
\hline & Sig. (2-tailed) & .050 & .000 & .000 & & .000 & .000 \\
\hline & $\overline{\mathrm{N}}$ & 100 & 100 & 100 & 100 & 100 & 100 \\
\hline \multirow[t]{3}{*}{ Fasilitas } & $\begin{array}{l}\text { Pearson } \\
\text { Correlation }\end{array}$ & $.231^{*}$ & $.451^{\text {s" }}$ & $.523^{\text {w. }}$ & $.741^{\prime \prime \prime}$ & 1 & $.681^{* 67}$ \\
\hline & Sig. (2-tailed) & .021 & .000 & .000 & .000 & & .000 \\
\hline & $\mathrm{N}$ & 100 & 100 & 100 & 100 & 100 & 100 \\
\hline \multirow[t]{3}{*}{$\begin{array}{l}\text { keputusan } \\
\text { menginap }\end{array}$} & $\begin{array}{l}\text { Pearson } \\
\text { Correlation }\end{array}$ & $.264^{* *}$ & $.475^{* *}$ & $.442^{* * *}$ & $.571^{* *}$ & $.681^{* *}$ & 1 \\
\hline & Sig. (2-tailed) & .008 & .000 & .000 & .000 & .000 & \\
\hline & $\mathrm{N}$ & 100 & 100 & 100 & 100 & 100 & 100 \\
\hline \multicolumn{8}{|c|}{ **. Correlation is significant at the 0.01 level(2-tailed). } \\
\hline
\end{tabular}

*Sumber: Data Kuesioner yang diolah (2019). 
Dari Tabel 8 terlihat bahwa terdapat hubungan antara variabel online review (informasi umum, ulasan, foto, lokasi, dan fasilitas) terhadap variabel Y (keputusan menginap) variabel X memiliki nilai signifikan < dari 0,05 dengan arah hubungan yang dimiliki yaitu positif. Adapun interpretasi koefisien korelasi untuk setiap variabel $\mathrm{X}$ terhadap variabel $\mathrm{Y}$ yaitu untuk informasi umum memiliki hubungan yang rendah dengan nilai person correlation $0.264>\mathrm{r}$ tabel (0.2006), untuk ulasan memiliki hubungan yang sedang dengan nilai person correlation $0.475>\mathrm{r}$ tabel $(0.2006)$, foto memiliki hubungan yang sedang dengan nilai person correlation $0.442>\mathrm{r}$ tabel $(0.2006)$, lokasi memiliki hubungan yang sedang dengan nilai person correlation $0.571>\mathrm{r}$ tabel (0.2006), dan untuk yang terakhir yaitu fasilitas memiliki hubungan yang kuat dengan nilai person correlation $0.681>\mathrm{r}$ tabel (0.2006). Hasil penelitian ini dapat dibandingkan dengan hasil penelitian sebelumnya yaitu Lestari (2017) menyatakan bahwa terdapat tiga variabel online review yang berpengaruh signifikan yaitu fasilitas, lokasi, dan ulasan. Analisis regresi berganda digunakan untuk mengetahui seberapa besar pengaruh variabel bebas yaitu : online review dalam Booking.com (X) yang terjadi dari nama dan alamat hotel (X1), ulasan atau komentar (X2), foto (X3), lokasi (X4), fasilitas (X5), terhadap keputusan menginap (Y) konsumen dalam keputusan pembelian jasa penginapan. Berikut hasil analisis regresi berganda dengan menggunakan bantuan program SPSS versi 25 dapat dilihat pada Tabel 9 di bawah ini :

19. Hasil Regresi Linear Berganda

\begin{tabular}{|c|c|c|c|c|c|c|}
\hline \multicolumn{7}{|c|}{ Coefficients $^{\mathbf{a}}$} \\
\hline \multirow{2}{*}{\multicolumn{2}{|c|}{ Model }} & \multicolumn{2}{|c|}{$\begin{array}{l}\text { Unstandardized } \\
\text { Coefficients }\end{array}$} & \multirow{2}{*}{$\begin{array}{l}\text { Standardized } \\
\text { Coefficients } \\
\text { Beta }\end{array}$} & \multirow{2}{*}{$\mathrm{T}$} & \multirow{2}{*}{ Sig. } \\
\hline & & $\mathrm{B}$ & Std.Error & & & \\
\hline \multirow[t]{6}{*}{1} & (Constant) & 2.846 & 1.580 & & 1.802 & .075 \\
\hline & Informasiumum & .053 & .132 & .033 & .400 & .690 \\
\hline & Ulasan & .244 & .122 & .177 & 1.999 & .048 \\
\hline & Foto & .119 & .150 & .070 & .797 & .428 \\
\hline & Lokasi & .176 & .140 & .135 & 1.253 & .213 \\
\hline & fasilitas & .595 & .155 & .457 & 3.840 & .000 \\
\hline
\end{tabular}

F hitung: 19.667

$\mathrm{R}: 0.715$

Sig F : 0.000

$\mathrm{R}^{2}: 0.511$

a. Dependent Variable: keputusan menginap

*Sumber: Kuesioner yang diolah(2019).

Berdasarkan persamaan regresi di atas, maka bentuk persamaan regresi linier berganda yang digunakan dalam penelitian ini sebagai berikut :

$\mathrm{Y}=2.846+0.053 \mathrm{X} 1+0.244 \mathrm{X} 2+0.119 \mathrm{X} 3+0.176 \mathrm{X} 4+0.595 \mathrm{X} 5$

Keterangan :

$\mathrm{Y}=$ Keputusan Menginap

a $\quad=$ Konstanta

$\mathrm{b} 1-\mathrm{b} 5=$ Koefisien regresi

$\mathrm{X} 1 \quad=$ Informasi Umum

$\mathrm{X} 2=$ Ulasan

$\mathrm{X} 3=$ Foto

$\mathrm{X} 4=$ Lokasi

$\mathrm{X} 5=$ Fasilitas 
Dari persamaan regresi berganda di atas, dapat menginformasikan bahwa :

1. Nilai konstanta sebesar 2.846 nilai konstanta positif menunjukan pengaruh positif artinya jika variabel $\mathrm{X}$ yang terdiri dari informasi umum, ulasan, foto, lokasi dan fasilitas dianggap 0 (nol) atau tidak diterapkan maka, keputusan konsumen untuk menggunakan jasa atau menginap di De Vins Sky Hotel Seminyak sebesar 2.846 satuan.

2. Informasi Umum mendapatkan nilai koefisiensi regresi yaitu 0.053 berarti bahwa jika informasi umum naik sebesar 1 satuan dan variabel lain tetap maka keputusan menginap akan naik sebesar 0,053 .

3. Ulasan mendapatkan nilai koefisiensi regresi yaitu 0.244 berarti bahwa jika ulasan naik sebesar 1 satuan dan variabel lain tetap maka keputusan menginap akan naik sebesar 0,244.

4. Foto mendapatkan nilai koefisiensi regresi yaitu 0.119 berarti bahwa jika foto naik sebesar 1 satuan dan variabel lain tetap maka keputusan menginap akan naik sebesar 0.119 .

5. Lokasi mendapatkan nilai koefisiensi regresi yaitu 0.176 berarti bahwa jika lokasi naik sebesar 1 satuan dan variabel lain tetap maka keputusan menginap akan naik sebesar 0.176.

6. Fasilitas mendapatkan nilai koefisiensi regresi yaitu 0.595 berarti bahwa jika fasilitas naik sebesar 1 satuan dan variabel lain tetap maka keputusan menginap akan naik sebesar 0.595,

Analisis Simultan Uji F dilakukan untuk melihat pengaruh secara simultan atau bersamaan antara variabel X (Online Review) terhadap variabel Y (Keputusan Menginap), maka perumusan hipotesis adalah sebagai berikut :

Ho1 : Tidak terdapat pengaruh yang positif dan signifikan secara simultan antara variabel informasi umum, ulasan, foto, lokasi, fasilitas terhadap keputusan wisatawan menginap di De Vins Sky Hotel.

Ha1 : Terdapat pengaruh yang positif dan signifikan secara simultan antara variabel informasi umum, ulasan, foto, lokasi, fasilitas terhadap keputusan wisatawan menginap di De Vins Sky Hotel.

Hasil uji secara simultan atau secara bersama - sama antara sub variabel X (Informasi umum, ulasan, foto, lokasi, fasilitas) terhadap variabel Y (Keputusan Menginap) dapat dilihat pada Tabel 10.

Tabel 10. Hasil UjiF

\begin{tabular}{|c|c|c|c|c|c|c|}
\hline ANOV/ & & & & & & \\
\hline Model & & Sum of Squares & Df & Mean Square & $\bar{F}$ & Sig. \\
\hline 1 & Regression & 253.158 & 5 & 50.632 & 19.667 & $.000^{\mathrm{b}}$ \\
\hline & Residual & 242.002 & 94 & 2.574 & & \\
\hline & Total & 495.160 & 99 & & & \\
\hline a.Depe & ident Variab & keputu san mengin & & & & \\
\hline b. Predi & ors: (Const & fa silita s, Inform & asiu & o, ula san, lokas & & \\
\hline
\end{tabular}

*Sumber: Data kuesioner yang diola h(2019).

Pada Tabel 10 dapat dilihat bahwa nilai Sig. adalah 0.000 maka $<0.05$, sehingga Ho1 ditolak. Cara berikutnya adalah membandingkan nilai $F$ hitung dengan $F$ tabel, dimana $F$ tabel $(\mathrm{n} 1=\mathrm{k}-1, \mathrm{n} 2$ $=\mathrm{n}-\mathrm{k})$ sehingga di dapat $\mathrm{F}$ tabel $(\mathrm{n} 1=5, \mathrm{n} 2=94) \mathrm{F}$ tabel sebesar 2,31 dan nilai $\mathrm{F}$ hitung adalah 19,667. Maka ditarik kesimpulan berdasarkan Tabel 4.12, bahwa F hitung $(19,667)>F$ tabel $(2,31)$ sehingga Ho1 ditolak. Jadi secara simultan informasi umum, ulasan, foto, lokasi, fasilitas berpengaruh positif dan signifikan terhadap keputusan menginap wisatawan pada De Vins Sky Hotel. Berikut kurva hasil uji F dapat dilihat pada Gambar 3 di bawah ini

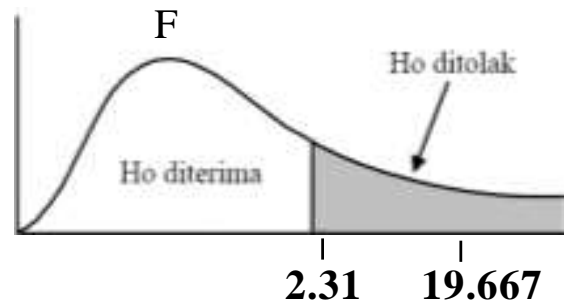

Gambar 3. Kurva UjiF 
Hasil penelitian ini sejalan dengan penelitian sebelumnya yaitu wati (2015) serta Lestari (2017) yang menyatakan bahwa terdapat pengaruh positif dan signifikan pada variabel Online Review secara simultan terhadap keputusan menginap yang membedakan adalah hasil dari $\mathrm{F}$ hitung.

Uji regresi parsial ( $t$-test) bertujuan untuk mengetahui apakah variabel bebas (Online Review yang terdiri dari informasi umum, ulasan, foto, lokasi, fasilitas) berpengaruh secara parsial terhadap variabel terikat ( Keputusan Menginap) pada De Vins Sky Hotel. Untuk melihat pengaruh secara parsial antara variabel $\mathrm{X}$ terhadap variabel $\mathrm{Y}$, maka perumusan hipotesis adalah sebagai berikut :

Ho2 : Tidak terdapat pengaruh yang positif dan signifikan secara parsial antara variabel informasi umum, ulasan, foto, lokasi, fasilitas terhadap keputusan wisatawan menginap di De Vins Sky Hotel.

Ha2 : Terdapat pengaruh yang positif dan signifikan secara parsialantara variabel informasi umum, ulasan, foto, lokasi, fasilitas terhadap keputusan wisatawan menginap di De Vins Sky Hotel. Adapun hasil perhitungan uji parsial dengan menggunakan SPSS versi 25 dapat dijelaskan sebagai berikut :

Tabel11. Hasil Ujit

\begin{tabular}{|c|c|c|c|c|c|c|}
\hline \multicolumn{7}{|c|}{ Coefficients $^{\mathrm{a}}$} \\
\hline \multirow[b]{3}{*}{ Model } & & \multirow{2}{*}{\multicolumn{2}{|c|}{ Unsta ndardized Coefficients }} & Standardized & \multirow[b]{3}{*}{$\mathrm{t}$} & \multirow[b]{3}{*}{ Sig. } \\
\hline & & & & Coefficients & & \\
\hline & & $\overline{\mathrm{B}}$ & Std.Error & Beta & & \\
\hline 1 & (Constant) & 2.846 & 1.580 & & 1.802 & .075 \\
\hline & Informasi umum & .053 & .132 & .033 & .400 & .690 \\
\hline & Ula san & .244 & .122 & .177 & 1.999 & .048 \\
\hline & Foto & .119 & .150 & .070 & .797 & .428 \\
\hline & Lokasi & .176 & .140 & .135 & 1.253 & .213 \\
\hline & fasilita s & .595 & .155 & .457 & 3.840 & .000 \\
\hline
\end{tabular}

Pada Tabel 11 dapat dilihat hasil dari uji t secara parsial antara sub variabel X (Online Review) terhadap variabel Y (Keputusan Menginap) dimana t tabel $(n-k)$ sehingga di dapat $t$ tabel $(100-6=94)$ $\mathrm{t}$ tabel sebesar 1,986 dan $\alpha 0.05$ sehingga didapat hasil sebagai berikut :

1. Variabel informasi umum (X1) memiliki t hitung sebesar 0,400 dan nilai sig. sebesar 0,690 karena nilai thitung $(0,400)<\mathrm{t}$ tabel $(1,986)$ dan nilai sig. $(0.690)>0.05$ maka dapat disimpulkan bahwa Ho1 diterima yaitu sub variabel informasi umum tidak berpengaruh secara parsial terhadap keputusan wisatawan menginap di De Vins Sky Hotel.

2. Variabel ulasan (X2) mendapatkan nilai t hitung sebesar 1,999 dan dengan nilai sig. 0,048 sehingga nilai t hitung $(1,999)>t$ tabel $(1,986)$ dan nilai sig. $0,048<0.05$ jadi Ho1 ditolak yaitu sub variabel ulasan berpengaruh positif dan signifikan terhadap keputusan wisatawan menginap di De Vins Sky Hotel.

3. Variabel foto (X3) memperoleh nilai t hitung yaitu 0.797 dan nilai sig. 0.428 jadi dapat dilihat bahwa nilai t hitung $(0.797)<\mathrm{t}$ tabel $(1,986)$ dan nilai sig. $(0.428)>0.05$ maka Hol diterima yang berarti sub variabel foto tidak berpengaruh secara parsial terhadap keputusan menginap tamu di De Vins Sky Hotel.

4. Variabel lokasi (X4) mendapatkan nilai t hitung yaitu 1,253 dan nilai sig. diperoleh 0,213 sehingga dapat disimpulkan $t$ hitung $(1,253)<t$ tabel $(1,986)$ dan nilai sig. $>0,05$ maka dari hasil tersebut berarti Hol diterima yang berarti bahwa lokasi tidak berpengaruh secara parsial terhadap keputusan menginap tamu di De Vins Sky Hotel.

5. Variabel fasilitas (X5) memperoleh nilai t hitung 3,840 dengan nilai sig. 0,000 maka dapat disimpulkan bahwa t hitung $(3,840)>\mathrm{t}$ tabel $(1,986)$ dan nilai sig. $<0,05$ yang berarti Hol di tolak dimana bahwa fasilitas berpengaruh positif secara parsial terhadap keputusan wisatawan menginap di De Vins Sky Hotel.

Berikut kurva hasil uji t dapat dilihat pada Gambar 4 di bawah ini : 


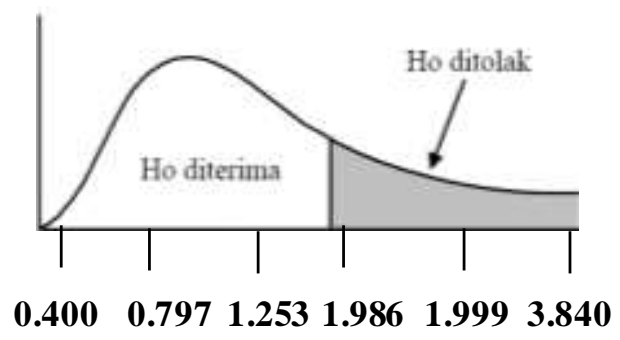

Gambar 4. Kurva Ujit

Hasil uji t ini dapat membuktikan bahwa variabel fasilitas dengan t hitung (3.840) memiliki pengaruh yang paling signifikan dari variabel lainnya seperti informasi umum, ulasan, foto, dan lokasi hal ini dilihat dari t hitung setiap variabel X. Hasil penelitian ini berbeda dengan hasil penelitian sebelumnya yaitu Wati (2015) yang menyatakan bahwa semua variabel $\mathrm{X}$ berpengaruh positif dan signifikan secara parsial dan ulasan merupakan variabel yang paling signifikan pengaruhnya terhadap keputusan menginap wisatawan namun hasil penelitian ini menyatakan bahwa hanya dua variabel $\mathrm{X}$ yang berpengaruh positif dan signifikan terhadap keputusan menginap secara parsial yaitu variabel ulasan dan fasilitas dan fasilitas merupakan variabel yang paling signifikan pengaruhnya terhadap variabel Y.

Analisis determinasi dilakukan untuk mengukur seberapa besar presentase perubahan yang diberikan varibel X (Online Review) terhadap variabel Y (Kputusan Menginap) atau dengan kata lain, nilai koefisien determinasi ini berguna untuk memprediksi dan melihat seberapa besar kontribusi variabel X (Online Review) secara simultan terhadap keputusan wisatawan menginap di De Vins Sky Hotel yang merupakan variabel Y pada penelitian ini dengan bantuan program SPSS versi 25. Hasil pengujian koefisien determinasi dapat dilihat pada Tabel 12 di bawah ini :

Tabel 12. Koefisien Determinasi

\begin{tabular}{lllll}
\hline \multicolumn{2}{l}{ Model Summary } & & \\
\hline Model & $\mathrm{R}$ & R Square & $\begin{array}{l}\text { Adjusted R } \\
\text { Square }\end{array}$ & $\begin{array}{l}\text { Std. Error of the } \\
\text { Estima te }\end{array}$ \\
\hline 1 & $.715^{\mathrm{a}}$ & .511 & .485 & 1.605 \\
\hline
\end{tabular}

a. Predictors: (Constant), fasilitas, Informasiumum, foto, ula san, lokasi

*Sumber: Data kuesineryang diolah (2019).

Berdasarkan Tabel 12 dapat terlihat $\mathrm{R}$ square $\left(\mathrm{R}^{2}\right)$ yang diperoleh ialah 0.511 dimana hal itu berarti 51,1\% keputusan menginap (variabel $\mathrm{Y}$ ) dipengaruhi atau dapat dijelaskan oleh sub variabel $\mathrm{X}$ (Online Review) yang terdiri dari informasi umum, ulasan, foto, lokasi dan fasilitas, sedangkan untuk sisanya yaitu $48,1 \%$ dapat dijelaskan atau dipengaruhi oleh variabel lainnya yang tidak termasuk atau di luar model yang tidak dijelaskan pada penelitian ini seperti peringkat hotel, jumlah ulasan, jumlah bintang pada online travel agent khususnya Booking.com.

\section{KESIMPULAN}

Berdasarkan hasil analisis data dan pembahasan yang telah diuraikan, maka dapat diambil simpulan bahwa variabel Online Review yaitu informasi umum, ulasan, foto, lokasi dan fasilitas berpengaruh positif dan signifikan terhadap variabel Y (Keputusan Menginap) secara simultan hal ini dibuktikan dengan hasil nilai $F$ hitung 19,667 yang dimana nilai $F$ hitung $>F$ tabel $(3,94)$ sehingga dengan kata lain semakin meningkatnya pengaruh online review pada booking.com maka meningkat pula keputusan wisatawan untuk menginap di De Vins Sky Hotel, Seminyak. Hasil uji t test diketahui hanya dua variabel yang berpengaruh secara parsial yaitu ulasan dan fasilitas dengan nilai masing masing t hitung adalah 1,999 dan nilai sig. 0,048 untuk ulasan, 3,840 dan nilai sig. 0,000 untuk fasilitas. Untuk variabel informasi umum, foto, lokasi pada online review (booking.com) tidak berpengaruh secara parsial terhadap keputusan wisatawan untuk menginap di De Vins Sky Hotel karena nilai t hitung yang dihasilkan lebih kecil dari $t$ tabel dan nilai sig. lebih besar dari 0,05. Berikutnya hasil determinasi yang diperoleh dari penelitian ini ialah R square (R2) yang diperoleh ialah 0.511 dimana hal itu berarti $51,1 \%$ keputusan menginap (variabel Y) dipengaruhi atau dapat dijelaskan oleh sub variabel X (Online 
Review) yang terdiri dari informasi umum, ulasan, foto, lokasi dan fasilitas, sedangkan untuk sisanya yaitu $48,1 \%$ dapat dijelaskan atau dipengaruhi oleh variabel lainnya yang tidak termasuk atau di luar model yang tidak dijelaskan pada penelitian ini seperti peringkat hotel, jumlah ulasan, jumlah bintang pada online travel agent khususnya Booking.com. Hasil uji t untuk penelitian ini adalah variabel informasi umum (X1) memiliki thitung sebesar 0,400, variabel ulasan (X2) mendapatkan nilai thitung sebesar 1,999, variabel foto (X3) memperoleh nilai t hitung yaitu 0.797 , variabel lokasi (X4) mendapatkan nilai t hitung yaitu 1,253, variabel fasilitas (X5) memperoleh nilai t hitung 3,840 dari hasil ini dapat dilihat untuk variabel fasilitas memiliki nilai tertinggi diantara variabel $\mathrm{X}$ lainnya maka kesimpulannya adalah fasilitas merupakan variabel yang paling signifikan pengaruhnya terhadap keputusan wisatawan menginap.

\section{DAFTAR PUSTAKA}

Amalia, Verina. 2013. "Analisis Pengaruh Pemanfaatan Situs TripAdvisor terhadap Keputusan Pembelian Kamar Hotel di Kota Bandung sebagai Destinasi Wisata”. Bandung: Universitas Pendidikan Indonesia.

Andayani, Henny. 2014. Manajemen Pemasaran Pariwisata. Yogyakarta: Graha Ilmu.

Anto, Dajan. 1996.Pengantar Metode Statistik, Edisi 8. Jakarta: PT Pustaka,LP3S.

Badan Pusat Statistik. 2017. Jumlah Kunjungan Wisatawan ke Bali. Bali.

Badan Pusat Statistik. 2017. Jumlah Pertumbuhan Hotel di Bali. Bali.

Budi, Permana. 2013. Manajemen Marketing Perhotelan. Yogyakarta: Andi.

Cunningham, Padraig, dkk. 2010. "Does TripAdvisor Makes Hotels Better”. Dublin : School of Science \& Informatics, University College Dublin.

Gay, L.R. dan Diehl, P.L. 1992. Research Methods for Business and Management. New York: MacMillan Publishing Company.

Gretzel, Ulricke. 2007. Role \& Impact of Online Travel Review. Texas: A\&M University.

Ghozali, Imam.2001. Aplikasi Analisis Multivariate Dengan Program SPSS.Semarang: Badan Penerbit Universitas Diponegoro.

Ika, Laras. 2017. "Analisis Pengaruh Situs TripAdvisor terhadap Keputusan Menginap Wisatawan di Pullman Bali Legian Nirwana Hotel and Resort". Denpasar: Universitas Udayana.

Kotler dan Amstrong. 2008. Prinsip-Prinsip Pemasaran. Jilid 1. Edisi dua belas.Jakarta:Erlangga.

Miguens, R. Baggio dan C. Costa. 2008. "Social Media \& Tourism Destination : TripAdvisor Case Study. Portugal : Advances in Tourism Research : $26-28$.

Mudambi, Susan dan David Schuff. 2010. "What Makes a Helpful Online Review”. Philadelpia :MIS Quarterly. Vol. 34, No $1: 185-200$.

Muljadi. 2009. Kepariwisataan dan Perjalanan. Jakarta: PT. Raja Grafindo Persada.

Nazir. 1998. Metode Penelitian. Jakarta : Rineka Cipta.

Pitana,Gede dan Surya Diarta. 2009. Pengantar Ilmu Pariwisata. Yogyakarta:Andi.

SK.Menhub.RI.No.PM 10/PW.391/PHB-77

Sugiyono.2007. Metode Penelitian Bisnis, Cetakan Ke-10. Bandung: CVAlfabeta.

Suharso dan Ana Rtoningsih. 2005. Kamus Besar Bahasa Indonesia. Semarang: Widya Karya.

Surat Keputusan Menparpostel No.KM/37/PW.340/MPPT-86, tentang peraturan usaha dan penggolongan hotel, Bab 1, Ayat (b)

Sutopo, HB. 2006. Metode Penelitian Kualitatif. Surakarta: UNS Press.

Swastha, Basu. 2016. Manajemen Pemasaran. Tangerang: Universitas Terbuka.

Suwena, Ketut dan Ngurah Widyatmaja.2010. Pengetahuan Dasar Ilmu Pariwisata.Denpasar: Universitas Udayana Press.

Tjiptono, Fandy. 2014. Pemasaran Jasa-Prinsip, Penerepan dan Penelitian.Yogyakarta: Andi.

Utama, Bagus Rai.2016. Metodologi Penelitian Pariwisata \& Hospitalitas. Denpasar: Pustaka Larasan.

Wati, Purnama.2005. "Analisis Pengaruh Online Review dalam TripAdvisorTerhadap Keputusan Menginap Wisatawan di Hotel Centra Taum Seminyak Badung Bali”.Denpasar: universitas udayana.

www.booking.com. 28 April $2019: 20.25$

Yazid. 1999. Pemasaran Jasa: Konsep dan Implementasi. Yogyakarta: Ekonisia FEUI. 